\title{
Effect of Nifedipine on Hippocampal Neuron Number in Penicillin-Induced Epileptic Rats
}

\author{
Nifedipinin Penisilin ile Deneysel Epilepsi Oluşturulan Suçanlarda \\ Hipokampal Nöron Kaybrna Etkisi
}

\author{
Ismail YILMAZ1 , Ilgaz AKDOGAN², Ertugrul KAYA³ , Goksin Nilufer YONGUC ${ }^{4}$ \\ ${ }^{1}$ Bozyaka Education and Research Hospital, Department of Medical Pharmacology, Izmir, Turkey \\ ${ }^{2}$ Pamukkale University, Faculty of Medicine, Department of Anatomy, Denizli, Turkey \\ ${ }^{3}$ Duzce University, Faculty of Medicine, Department of Medical Pharmacology, Duzce, Turkey \\ 4 Izmir University, Faculty of Medicine, Department of Anatomy, Izmir, Turkey
}

Corresponding Author: Ilgaz AKDOGAN / E-mail: iakdogan@pau.edu.tr

\begin{abstract}
AIM: Epileptic seizures lead to neuronal loss in the hippocampus. Experimental epilepsy can be induced by direct application of various chemicals to cerebral cortex. Nifedipine is an L-type voltage-dependent calcium channel blocker. In spite of several studies that show the seizure-suppressing effects of nifedipine, it has been shown that nifedipine does not suppress but conversely increases epileptic seizures. Similarly, contradictory effects of nifedipine have been reported, such as neuroprotection, failed neuroprotection and neurotoxicity. We therefore aimed to investigate the effect of nifedipine on hippocampal neuronal loss in penicillin induced epileptic rats in this study.

MATERIAL and METHODS: The effect of nifedipine on total hippocampal neuron number was estimated by using the optical fractionator method (an unbiased stereological method) in penicillin-G induced epileptic rats.

RESULTS: The total number of hippocampal neurons in the control group was $183687 \pm 3184$. In the penicillin-induced group, the total neuron number significantly decreased to $146318 \pm 3042$ compared to the control group. In the nifedipine group, the neuron number significantly decreased to $128873 \pm 1157$ compared to both control and penicillin-induced groups.

CONCLUSION: Nifedipine increased neuronal loss and did not suppress epileptic seizures in penicillin-induced epileptic rats. Nifedipine could not protect against hippocampal neuronal loss in penicillin-induced epileptic rats.
\end{abstract}

KEYWORDS: Penicillin epilepsy model, Nifedipine, Hippocampus, Neuron number, The optical fractionator method, Rat, Epilepsy, Seizure

öz

AMAÇ: Epileptik nöbetler hipokampusta nöron kaybına yol açmaktadır. Çeşitli kimyasalların beyin korteksine direkt olarak uygulanmasıyla deneysel epilepsi oluşturulabilir. Nifedipin, L-tipi voltaj bağımlı kalsiyum kanal blokörüdür. Nifedipinin nöbet baskılayıcı etkilerini gösteren çeşitli çalışmalar bulunduğu gibi, epileptik nöbetleri baskılamadığı tam tersine arttırdığı da gösterilmiştir. Benzer şekilde, nifedipinin çelişkili etkileri bildirilmiştir; olumlu - olumsuz nöroprotektif (nöron koruyucu) ve nörotoksisite gibi. Bu nedenle, bu çalışmada, penisilin ile deneysel epilepsi oluşturulan sıçanlarda nifedipinin hipokampal nöron kaybı üzerine etkisini araştırmayı amaçladık.

YÖNTEM ve GEREÇLER: Nifedipinin penisilin G ile deneysel epilepsi oluşturulan sıçanlarda toplam hipokampal nöron sayısına etkisi tarafsız (objektif) bir stereolojik metot olan optik parçalama yöntemi ile değerlendirildi.

BULGULAR: Kontrol grubunun toplam hipokampal nöron sayısı $183687 \pm 3184$ idi. Penisilin grubunun toplam nöron sayısı kontrol grubuna göre anlamlı olarak düşüktü (146318 \pm 3042$)$. Penisilin+nifedipin grubunun toplam nöron sayısı (128873 \pm 1157$)$ hem kontrol hem de penisilin grubuna göre istatistiksel olarak anlamlı olarak azalmış bulundu.

SONUÇ: Nifedipinin epileptik sıçanlarda nöron kaybını arttırdığı ve epileptik nöbetleri baskılamadığı ortaya kondu. Nifedipin, penisilin ile deneysel epilepsi oluşturulan sıçanlarda ortaya çıkan nöron kaybına karşı koruyucu bir etki göstermedi.

ANAHTAR SÖZCÜKLER: Penisilin epilepsi modeli, Nifedipin, Hipokampus, Nöron sayısı, Optik parçalama yöntemi, Sıçan, Epilepsi, Nöbet

\section{INTRODUCTION}

Previous clinical and experimental epilepsy studies have shown that the epileptic seizures activated by the hyperexcitability of the hippocampus may cause irreversible pathological alterations in this area. These alterations include neuronal loss, neuronal degeneration and volume decrease in the hippocampus $(14,51)$.
Chemical convulsants are widely used as a simple and rapid seizure-inducing technique and penicillin is a common agent. The penicillin-epilepsy (PE) model has been commonly used in experimental animal studies to investigate the neuronal basis of epilepsy. In the PE model, the seizures are characterized by the reduced inhibitory effect of GABA in the cortex (18). However, increased glutamate secretion has been shown in 
the frontoparietal cortex (6), hippocampal neuron culture (10) and motor cortex (17). Our previous studies have shown that the PE model decreases neuron number in the pyramidal cell layers of the CA1, CA2 and CA3 fields of the hippocampus $(2,3,53)$.

Calcium is a major signaling molecule and has been implicated to play an important role in epileptogenesis and neuronal death in various acute neurological diseases. During seizure, inreased intracellular concentrations and decreased extracellular concentrations of calcium have been shown (15). $\mathrm{Ca}^{+2}$ is described as the primary mediator of "excitotoxic" neuronal damage. $\mathrm{Ca}^{+2}$ entry starts a cascade of biochemical reactions within the neuron that leads to its death. Depending on the availability of energy, necrosis and apoptosis or both can occur. Both necrotic and apoptotic cell death is associated with $\mathrm{Ca}^{+2}$ entry into the cells during status epilepticus (23).

Calcium channel blockers may have a potential role since the influx of calcium ions into neurons is thought to be an important feature of epileptogenesis. Animal studies and limited clinical trials have also suggested that calcium channel blockers may be potentially useful in epilepsy. More importantly, elevated levels of intracellular $\mathrm{Ca}^{+2}$ are thought to activate numerous $\mathrm{Ca}^{+2}$-dependent processes that lead to cell death. Blockage of $\mathrm{Ca}^{+2}$ channels may play a key role in preventing these events $(23,48)$.

Nifedipine is a dihydropyridine type voltage-dependent calcium channel blocker. It has been shown that this drug displays antiepileptic activity in pentylenetetrazol (PTZ)induced epilepsy $(25,36)$, maximal electroshock (MES)-evoked seizures in a dose dependent manner (19), hippocampalkindled seizures (46) and picrotoxin-induced seizures (44). Contrary to expectations, nifedipine did not influence aminophylline-induced seizures (12), seizures elicited by MES (36) and the protective action of diazepam against PTZ-induced seizures (13). Further, nifedipine decreased topiramate activity in WAG/Rij rats but paradoxically enhanced it in $\mathrm{lh} / \mathrm{lh}$ mice (41) and increased epileptiform activity in spontaneous seizures in the isolated mouse hippocampus (16). In addition to these, clinical studies have also been performed in epileptic patients to investigate the effects of nifedipine. They have failed to confirm its efficacy in epilepsy, but EEGs suggested a small improvement with higher dose nifedipine $(26,27)$.

Nifedipine also has effects on neuronal death. It has been shown to protect in Alzheimer's disease in cell cultures (38), brevetoxin-induced excitotoxicity (7), 4-hydroxynonenal (4HN)-induced neurotoxicity in hippocampal neurons (1), AMPA and kainate-induced neurotoxicity (47). On the contrary, nifedipine failed to protect against kainate (30), glutamate (34) and $4 \mathrm{HN}$-induced neurotoxicity in cerebellar granule neurons (CGNs) (4). It also potentiates kainate neurotoxicity in CGNs $(28,29)$.

Nifedipine has clearly been shown to have variable and even contradictory (beneficial or detrimental) effects in different studies and its neuroprotective or neurotoxic mechanisms remain to be clarified in other, still not investigated models, such as PE. Accordingly, we aimed to investigate the effect of nifedipine on hippocampal neuronal loss in the PE model in the present study.

\section{MATERIAL and METHODS}

\section{Animals}

Male Sprague-Dawley rats weighing 250-300 g (Pamukkale University Experimental Animal Laboratory, Denizli, TURKEY) were used for this study. The rats were housed in cages (4-5 rats per cage). All cages were kept in an animal room with a controlled temperature $\left(23 \pm 2^{\circ} \mathrm{C}\right)$ and relative humidity $(60 \pm 5 \%)$ with lights on from 7:00 to 19:00. All procedures in the present study were conducted according to a protocol approved by the ethical committee. All efforts were made to minimize animal suffering and to reduce the number of animals used (53).

\section{Experimental Procedure}

A total of 15 rats were randomly divided into three groups; control group ( $8 \mu \mathrm{l}$ saline injected intracortically, $\mathrm{n}=5$ ), penicillin group (500 IU Penicillin-G in a volume of $8 \mu \mathrm{l}$ injected intracortically, $n=5)$, penicillin+nifedipine group (500 IU Penicillin-G in a volume of $8 \mu$ injected intracortically and $10 \mathrm{mg} / \mathrm{kg}$ nifedipine injected i.p. at the same time as penicillin, $\mathrm{n}=5$ ). For intracortical injections, rats were anaesthetized with Xylazine (10 mg/kg, i.p.) and Ketamine (90 mg/kg, i.p.). Saline or penicillin was injected to the right cerebral cortex intracortically by using a stereotaxic device (Stoelting, Wood Dale, IL, USA). The coordinates $(\mathrm{mm})$ applied were relative to the skull surface, with the upper incisor bar $3.4 \mathrm{~mm}$ below the level of the interaural line, according to the rat brain atlas (37): posterior to the bregma $A P=-2$; right to the midsagittal line, $\mathrm{L}=2 \mathrm{~mm}$, and dorsoventral, $\mathrm{DV}=2$.

\section{Neuronal Counts and the Optical Fractionator}

A week later, all animals were decapitated; their brains were removed by craniotomy. The brains were immediately frozen in a cryostat (Leica CM3050, Bensheim, Germany) at $-50{ }^{\circ} \mathrm{C}$. Frozen brains were cut in the horizontal plane with a thickness of $150 \mathrm{~mm}$ at $-15^{\circ} \mathrm{C}$ in cryostat. Sections stained with haematoxylin and eosin.

The total neuron number was estimated by the optical fractionator method in the pyramidal cell layer of the CA1, CA2 and CA3 fields of the hippocampus (49). In order to avoid the effect of local intracortical injection, estimation of the number of neurons in each group was performed in the left hippocampus (Figure $1 \mathrm{~A}-\mathrm{C}$ ).

\section{Sections}

The systematic random sampling scheme was used to choose sections. Accordingly, one of the first two sections in the series was chosen randomly as the first section. This section and every second following sections were stained with hematoxylin-eosin to use for counting neurons. Thus the section sampling fraction (ssf) was $1 / 2$. 

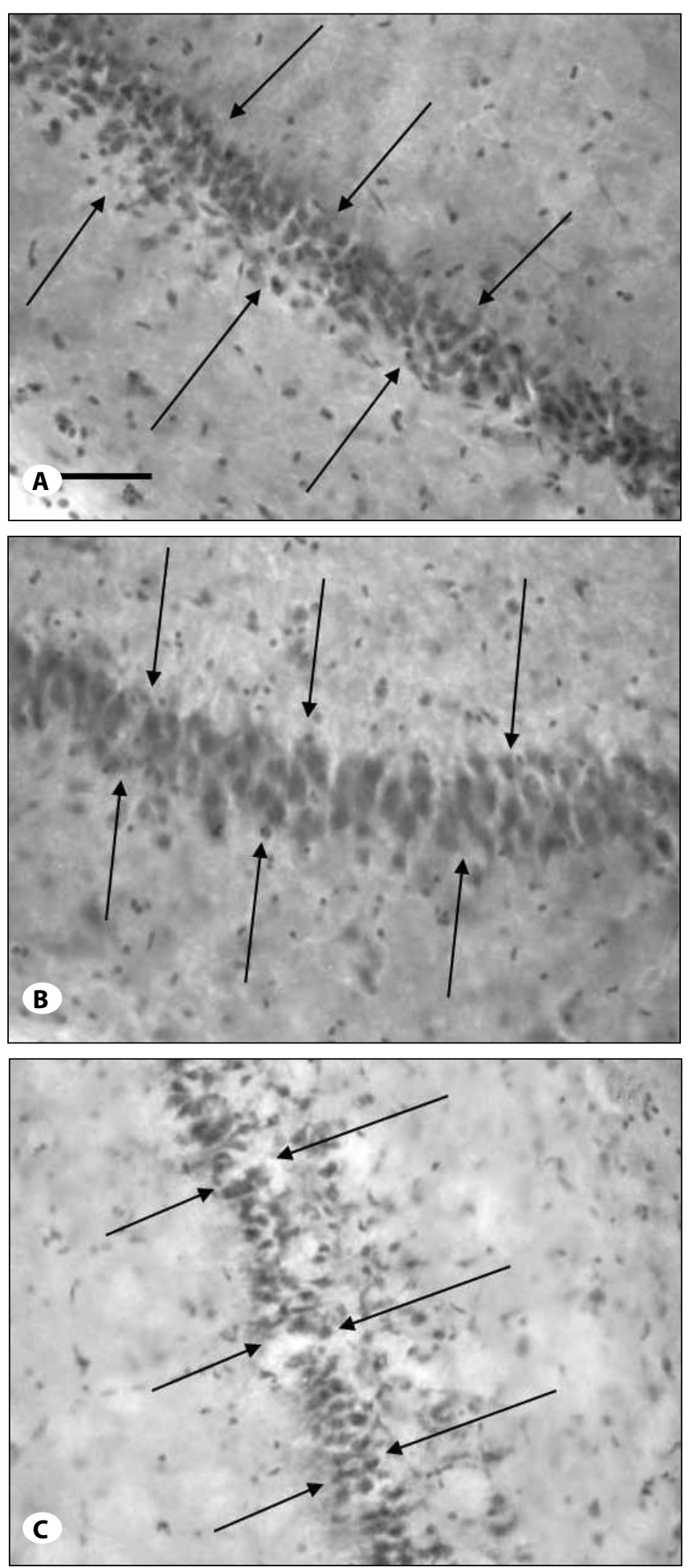

Figure 1: Comparative microphotograph of the hippocampal sections. The sections belong to the left hippocampus of the studied groups and were taken from similar levels. Arrows indicate the borders of the pyramidal cell layer studied. A) Control group, B) Penicillin group, C) Penicillin+nifedipine group (Scale bar $=50 \mu \mathrm{m}$ for all panels) (Stained with hematoxylin-eosin and 40x magnification).

\section{Sectional area}

In each of the chosen sections, neurons were counted with optical dissectors at the predetermined $\mathrm{x}, \mathrm{y}$ axis in the CA1CA3 fields of the hippocampus. The predetermined " $x$ " and " $y$ " steps were $300 \mathrm{~mm}$. Microscopic images obtained from pyramidal cell layers in the CA1, CA2 and CA3 fields of the hippocampus using an X100 oil objective (N.A.=1.25) were transferred to a monitor. An unbiased counting frame (Gundersen's unbiased counting frame) (49) was then superimposed on the monitor image of the section. The area of the counting frame of the dissector, a (frame), was known $\left(20 \mathrm{~mm} \times 20 \mathrm{~mm}=400 \mathrm{~mm}^{2}\right.$ ) relative to the area associated with each $x$, $y$ movement, a ( $x$, y step). Thus, the area sampling fraction (asf) $=a$ (frame) / a ( $x, y$ step).

\section{Section thickness}

At each step in the CA1-CA3 fields of hippocampus to be sampled, the neuronal nuclei were first observed under the frame. Afterwards, the plane of focus was moved $5 \mathrm{~mm}$ into the section. The counting frame was then focused through the thickness of $30 \mathrm{~mm}$ into the section and the number of neuronal nuclei was counted according to the rules of unbiased counting (Q)). Thus, the height ( $h$ ) of the dissector was $30 \mathrm{~mm}(\mathrm{~h}=30 \mathrm{~mm})$.

At each step in the CA1-CA3 fields of hippocampus to be sampled, the distance between the positions of the stage where the neuronal nuclei of first layer came into focus from above and below the section (i.e., the top and bottom surfaces) was determined. The distance in between the top and the bottom surfaces was measured. The mean thickness (t) of the section was calculated for each of the section used in the analysis. Thus, the thickness sampling fraction (tsf) = $h$ (the height of the dissectors) / $t$ (the mean of the section thickness).

Neurons were counted in a known sampled fraction of the hippocampus. The total number of neurons in the CA1-CA3 fields of the hippocampus (N) was estimated as;

$N=\Sigma Q^{-} \times(1 /$ ssf $) \times(1 /$ asf $) \times(1 /$ tsf $)(42,49)$

$\Sigma \mathrm{Q}:$ The total number of neurons counted in the height of the dissectors on the sampled sections.

\section{Statistical Analysis}

Statistical analyses for neuron counts were performed using the Kruskal-Wallis variance analysis. Subgroups were compared with each other using the non-parametric MannWhitney $\mathrm{U}$ test. A $p$-value $<0.05$ was taken as statistically significant. Since the random sampling method was used during neuron count, results were expressed as mean \pm standard error of the mean (S.E.M.).

\section{RESULTS}

In the penicillin group, the seizures were characterized by focal commencement (tremor and convulsion in fore limbs) and then generalized to the hind limbs and the whole body. 


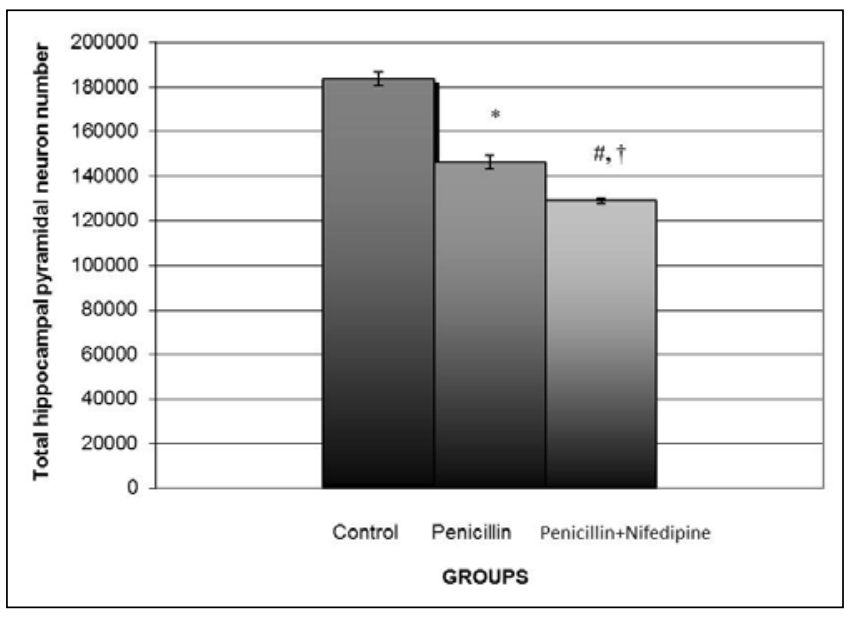

Figure 2: Means of total hippocampal pyramidal neuron numbers in groups. *; Neuron number significantly decreased in penicillin group compared with control group $(p<0.05$; Mann Whitney $U$ ). \#, †; The neuron number significantly decreased in the penicillin+nifedipine group compared with the control and penicillin groups, respectively $(p<0.05$ for both; Mann Whitney U).

Hyperactivity $(80 \%)$, ataxia $(60 \%)$, jumping $(60 \%)$, rotating $(40 \%)$, tail erection $(40 \%)$, rolling $(40 \%)$, shaking $(40 \%)$ and perioral movements $(60 \%)$ were observed in the penicillin group after the clonic and myoclonic seizures. In the penicillin+nifedipine group, rats also showed hyperactivity $(80 \%)$, ataxia $(60 \%)$, jumping $(80 \%)$, rotating $(40 \%)$, tail erection $(60 \%)$, rolling $(40 \%)$, shaking $(40 \%)$ and perioral movements $(60 \%)$ after the development of clonic and myoclonic seizures. Although no statistical results are presented, it was clearly observed that nifedipine did not suppress epileptic seizures in the PE model. No behavioral change was observed in the control group.

Pyramidal neurons were counted by using the optical fractionator method, a stereological method, which is believed to be a more unbiased, reliable, and effective method compared to nonstereological methods $(42,49)$. In addition, a coefficient (CE) value lower than $10 \%$ is in the acceptable range (20). In our study, calculated CE values were below 10 $\%$ for all animals. In the control group, the total hippocampal pyramidal neuron number was (mean \pm S.E.M) $183687 \pm$ 3184. In the penicillin group, the neuron number significantly decreased to $146318 \pm 3042$ compared with the control group $(p=0.008$, Mann-Whitney $U)$. In the penicillin+nifedipine group, the neuron number significantly decreased to 128873 \pm 1157 compared with both the penicillin and control groups ( $p=0.008$ for both, Mann-Whitney U) (Figure 1 A-C, Figure 2).

\section{DISCUSSION}

In this study, the seizures started after 2-4 $\mathrm{min}$, a result consonant with those reporting seizures after 2-5 $\mathrm{min}$ $(3,53)$. In line with that reported in our previous study (53), generalization of the seizures after $30-40 \mathrm{~min}$ and perioral movements, gnawing, ataxia, tail erection, circling, revolving and sudden jumps symptoms were observed. In the present study, even though no statistical results were presented, epileptic seizures were also observed in all rats of penicillin+nifedipine group. These observations are in agreement with Derchansky et al. In their study, it was demonstrated that the epileptiform activity became enhanced and more frequent following nifedipine administration (16). Also, Otoom and Hasan reported that nifedipine did not significantly alter the latency of onset of clonic seizure in doses of $5 \mathrm{mg} / \mathrm{kg}$, but increased the latency of onset in doses of $20 \mathrm{mg} / \mathrm{kg}$ in picrotoxin-induced seizure. Additionally, in the abovementioned study, nifedipine (in doses of $10 \mathrm{mg} / \mathrm{kg}$ ) did not reduce the incidence of clonic seizures, but inhibited tonic seizures and the progression of clonic seizures into maximal tonic seizures in four of eight animals (35). On the other hand, there are some studies that report opposing findings in the literature $(16,19,22,25,26,36,44,46)$.

The unpredictable effects of nifedipine on hippocampal neuronal loss indicates that there may be a drug interaction between penicillin and nifedipine. Although the literature has not provided any information on pharmacodynamic interactions between penicillin and nifedipine, several studies have indicated that these drugs may interact pharmacokinetically $(24,50)$. However, these studies do not explain the interference with the central nervous system and particularly with the neuronal loss.

The pyramidal neurons in the hippocampus are highly sensitive to anoxia and ischemia, including those induced by epileptic seizure (9). This property can be attributed to the histological characteristics of the hippocampus, which is composed of three layers, compared to the six-layer structure of the cerebral cortex (8). The pathological changes in the hippocampus and other limbic structures are the hallmark of epilepsy both in human epilepsy and in experimental animal epilepsy models. Hippocampal sclerosis and pyramidal neuronal loss are the most frequent pathological changes observed in post-extended seizure activities (39).

In recent years, estimating the total neuron number in the pyramidal layer of the hippocampus by using the stereological methods is believed to be more reliable, unbiased and effective compared to nonstereological methods used in the analysis of three-dimensional biological structures $(42,49)$. In the present study, the stereological method was used to estimate the total neuron number in the CA1, CA2 and CA3 fields of the hippocampus. The subiculum, presubiculum, CA2 field and dentate gyrus are relatively more resistant to epileptic seizures, whereas prominent changes could be observed in the CA1, CA3 and CA4 fields. The CA4 corresponds to the hilus of the dentate gyrus, and has different anatomical and histological characteristics $(39,49)$. Accordingly, the CA4 had been either excluded from neuronal counting studies $(2,53)$ or considered separately from the CA1 and CA3 fields (49). Neuronal counting was therefore carried out in the CA1 and $C A 3$, and the in-between CA2 fields, whereas the CA4 
field was excluded in our present study. The results revealed a prominent decrease in the number of hippocampal neurons in the PE rats. These are in agreement with our previous studies carried out in the hippocampal CA1, CA2 and CA3 fields $(2,53)$.

In experimental epilepsy, neuronal loss commences within hours after the appearance of seizures (5). The seizures persist for several days when cytokines and other cytotoxics (glutamate) are released (21). In the present study, rats were injected with penicillin and nifedipine, and the effects were investigated one week later. It has been known that alterations of voltage-dependent calcium channels occur in the hippocampus of patients and laboratory animals with temporal lobe epilepsy. However, these changes were reported mainly in hippocampal principal cells, i.e., pyramidal neurons in the CA1-3 fields and granule cells in the dentate gyrus instead of interneurons or mossy cells because of the lack of detailed distribution of voltage-dependent calcium channels in nonprincipal cells (52).

Contrary to what some studies suggest $(7,38,47)$, the present study revealed that nifedipine causes increased hippocampal neuronal loss in the PE model. In agreement with our findings, recent studies have suggested that nifedipine significantly attenuated $A \beta 1-42$-induced apoptosis but had no effect on A $\beta 1-42^{\text {Met35-Ox }}$ neurotoxicity in Alzheimer's disease (38), did not protect cerebellar granule neurons against $4 \mathrm{HN}$-induced neuronal death (4), had no effect on cell viability when applied alone or with GTS-21 (a7 agonist) in nerve growth factor (NGF)-deprived PC12 cells (40) and failed to protect rat hippocampal neurons from kainite toxicity (30). Moreover, nifedipine attenuated survival of cerebellar granule neurons in $25 \mathrm{mM} \mathrm{K}^{+}$(11) and potentiated kainate neurotoxicity in cerebellar granule neurons $(28,29)$. Leski et al. demonstrated that calcium entry through L-type voltage-gated calcium channels protects against kainate neurotoxicity and that nifedipine reduced calcium levels following kainate stimulation by approximately $50 \%$. In these studies, they also found a dose-dependent increase in the neurotoxic effects of nifedipine. At $10 \mathrm{mM}$ or above, nifedipine caused increased cell death in the control, while at $3 \mathrm{mM}$ or lower less, death was observed in the kainate-treated samples. Membrane rupture due to decreased adenylate energy charge (29) and severely damaged mitochondria (28) has been blamed for neuronal death following combined kainate/nifedipine application.

In addition to the above-mentioned possible mechanisms, $P E$ increases glutamatergic activity $(6,17)$, whereas excitatory aminoacid inhibitors could abolish EEG spikes in the PE model (31). Moreover, PE increases glutamate level in cerebrospinal fluid (43), and activates NMDA receptors $(10,54)$ that could lead to convulsion and neuronal degeneration and death (45). Excitotoxicity results from activation of specific glutamate receptors, with resultant elevation of intracellular $\mathrm{Ca}^{+2}$. Nifedipine had only a slight effect on the glutamate-induced increase in $\mathrm{Ca}^{+2}$, suggesting that L-type $\mathrm{Ca}^{+2}$ channels, at least, were not responsible and in addition to nifedipine could not prevent glutamate-induced cell death (34). Glutamate becomes neurotoxic to CGNs via the NMDA receptor when intracellular energy levels are reduced (32). In our present study, these above-mentioned mechanisms may have played role in the increased neuron loss of the penicillin+nifedipine group.

In conclusion, we have shown that nifedipine leads to increased hippocampal neuronal loss in the PE model in our present study. In the future, planning novel studies especially for understanding the molecular basis of neuron loss will provide considerable advantages. However, investigators should consider the lack of experimental models that fully evaluate a complex disorder such as epilepsy and perform their studies using different animal models of epilepsy and also with different doses of nifedipine.

\section{REFERENCES}

1. Akaishi T, Nakazawa K, Sato K, Ohno Y, Ito Y:4-Hydroxynonenal modulates the long-term potentiation induced by L-type $\mathrm{Ca}^{+2}$ channel activation in the rat dentate gyrus in vitro. Neurosci Lett 370(2-3):155-159, 2004

2. Akdogan I, Adiguzel E, Yilmaz I, Ozdemir MB, Sahiner $M$, Tufan AC: Penicillin-induced epilepsy model in rats: Dosedependant effect on hippocampal volume and neuron number. Brain Res Bull 77:172-177, 2008

3. Akdogan I, Unal N, Adiguzel E: Estimation of the number of neurons in the hippocampus of rats with penicillin induced epilepsy. Image Analysis and Stereology 21:117-120, 2002

4. Arakawa M, Ishimura A, Arai Y, Kawabe K, Suzuki S, Ishige K, Ito $\mathrm{Y}$ : N-Acetylcysteine and ebselen but not NFD protected cerebellar granule neurons against 4-hydroxynonenal-induced neuronal death. Neurosci Res 57:220-229, 2007

5. Auer RN, Siesjö BK: Biological differences between ischemia, hypoglycemia, and epilepsy. Ann Neurol 24:699-707, 1988

6. Avoli M, Brancati A, Pacitti C, Barra PF: Neuronal responses to putative neurotransmitters during penicillin epileptogenesis. Neuroscience 7(8):1955-1961, 1982

7. Berman FW, Murray TF: Brevetoxin-induced autocrine excitotoxicity is associated with manifold routes of $\mathrm{Ca}^{2+}$ influx. J Neurochem 74:1443-1451, 2000

8. Berry M, Bannister LH, Standring SM: Nervous system. In: Williams PL (ed), Gray's Anatomy, 38th ed. NewYork: Churchill Livingstone, 1995:901-1399

9. Clarck DL, Boutros NN: The brain and behavior: An introduction to behavioral neuroanatomy. Malden, Mass, USA: Blackwell Science, 1999

10. Chen X, Sheng C, Zheng X: Direct nitric oxide imaging in cultured hippocampal neurons with diaminoanthraquinone and confocal microscopy. Cell Biology International 25(7): 593-598, 2001

11. Collins A, Larson MK, Pfaff JE, Ishmael JE: Survival of SwissWebster mouse cerebellar granule neurons is promoted by a combination of potassium channel blockers. Toxicol Lett 171: 60-68, 2007 
12. Czuczwar SJ, Chodkowska A, Kleinrok Z, Malek U, JagiełłoWójtowicz E: Effects of calcium channel inhibitors upon the efficacy of common antiepileptic drugs. Eur J Pharmacol 176: 75-83, 1990

13. Czuczwar SJ, Malek U, Kleinrok Z: Influence of calcium channel inhibitors upon the anticonvulsant efficacy of common antiepileptics against pentylenetetrazol-induced convulsions in mice. Neuropharmacology 29(10): 943-948, 1990

14. Dam AM: Hippocampal neuron loss in epilepsy and after experimental seizures. Acta Neurol Scandinav 66:601-642, 1982

15. Delorenzo RJ, Sun DA, Deshpande LS,. Cellular mechanisms underlying acquired epilepsy: the calcium hypothesis of the induction and maintenance of epilepsy. Pharmacol Ther 105, 229-266, 2005.

16. Derchansky M, Shahar E, Wennberg RA, Samoilova M, Jahromi SS, Abdelmalik PA, Zhang L, Carlen PL: Model of frequent, recurrent, and spontaneous seizures in the intact mouse hippocampus. Hippocampus 14(8): 935-947, 2004

17. El-Yamany NA, Horn E: Time courses of aspartate and glutamate concentrations in the focus area during penicillin induced epileptiform activity in awake rats. Arch Ital Biol 140(1): 13-30, 2002

18. Fisher RS: Animal models of the epilepsies. Brain Research Reviews 14: 245-278, 1989

19. Gasior M, Borowicz K, Kleinrok Z, Starownik R, Czuczwar SJ: Anticonvulsant and adverse effects of MK-801, LY 235959, and GYKI 52466 in combination with $\mathrm{Ca}^{2+}$ channel inhibitors in mice. Pharmacol Biochem Behav 56: 629-635, 1997

20. Gundersen HJG, Jensen EB: The efficiency of systematic sampling in stereology and its prediction. J Microsc 147: 229-263, 1987

21. Jankowsky JL, Patterson PH: The role of cytokines and growth factors in seizures and their sequelae. Prog Neurobiol 63(2): 125-149, 2001

22. Karpova MN, Pankov Olu, Kryzhanovskil̆ GN, Glebov RN: Antiepileptic effects of nifedipine. Biull Eksp Biol Med 112(9):260-262, 1991

23. Kulak W, Sobaniec W, Wojtal K, Czuczwar SJ: Calcium modulation in epilepsy. Pol J Pharmacol 56: 29-41, 2004

24. Lang CC, Jamal SK, Mohamed Z, Mustafa MR, Mustafa AM, Lee TC: Evidence of an interaction between nifedipine and nafcillin in humans. Br J Clin Pharmacol 55(6):588-590, 2003

25. Larkin JG, Besag FM, Cox A, Williams J, Brodie MJ: Nifedipine for epilepsy? A double-blind, placebo-controlled trial. Epilepsia 33: 346-352, 1992

26. Larkin JG, Binnie CD, Brodie MJ: Calcium antagonism: A role in the treatment of epilepsy? Journal of Epilepsy 5(1):38-48, 1992

27. Larkin JG, Thompson GG, Scobie G, Forrest G, Drennan JE, Brodie MJ: Dihydropyridine calcium antagonists in mice: Blood and brain pharmacokinetics and efficacy against pentylenetetrazol seizures. Epilepsia 33(4): 760-769, 1992
28. Leski ML, Hassinger LC, Valentine SL, Baer JD, Coyle JT: L-type calcium channels reduce ROS generation in cerebellar granule cells following kainate exposure. Synapse 43:30-41, 2002

29. Leski ML, Valentine SL, Coyle JT: L-type voltage-gated calcium channels modulate kainic acid neurotoxicity in cerebellar granule cells. Brain Res 828: 27-40, 1999

30. Li SY, Ni JH, Xu DS, Jia HT: Down-regulation of GluR2 is associated with $\mathrm{Ca}^{2+}$-dependent protease activities in kainate-induced apoptotic cell death in cultured (correction of culturd) rat hippocampal neurons. Neurosci Lett 352: 105-108, 2003

31. Loeb C, Patrone A, Besio G, Balestrino M, Mainardi P: The excitatory amino acid antagonist amino-phosphono-valeric acid (APV) provides protection against penicillin-induced epileptic activity in the rat. Epilepsy Res 6(3):249-251, 1990

32. Novelli A, Reilly JA, Lysko PG, Henneberry RC: Glutamate becomes neurotoxic via the N-methyl-D-aspartate receptor when intracellular energy levels are reduced. Brain Res 451(12): 205-212, 1988

33. Otori Y, Kusaka S, Kawasaki A, Morimura H, Miki A, Tano Y: Protective effect of nilvadipine against glutamate neurotoxicity in purified retinal ganglion cells. Brain Res 961(2): 213-219, 2003

34. Otori Y, Wei JY, Barnstable CJ: Neurotoxic effects of low doses of glutamate on purified rat retinal ganglion cells. Invest Ophthalmol Vis Sci 39(6): 972-981, 1998

35. Otoom S, Hasan Z: Nifedipine inhibits picrotoxin-induced seizure activity: Further evidence on the involvement of L-type calcium channel blockers in epilepsy. Fundamental \& Clinical Pharmacology 20:115-119, 2006

36. Palmer GC, Stagnitto ML, Ray RK, Knowles MA, Harvey R, Garske GE: Anticonvulsant properties of calcium channel blockers in mice: N-methyl-D-,L-aspartate- and Bay $\mathrm{K}$ 8644-induced convulsions are potently blocked by the dihydropyridines. Epilepsia 34: 372-380, 1993

37. Paxinos G, Watson C: The rat brain in stereotaxic coordinates. Amsterdam, Boston, Heidelberg: Elsevier Academic Press, 6th ed. 2007

38. Piacentini R, Ripoli C, Leone L, Misiti F, Clementi ME, D'Ascenzo M, Giardina B, Azzena GB, Grassi C: Role of methionine 35 in the intracellular $\mathrm{Ca}^{2+}$ homeostasis dysregulation and $\mathrm{Ca}^{2+}$ dependent apoptosis induced by amyloid beta-peptide in human neuroblastoma IMR32 cells. J Neurochem 107: 1070-1082, 2008

39. Proper EA, Hoogland G, Van Veelen CWM, De Graan PNE: Morphological changes in the human epileptogenic hippocampus. Neuroscience Research Communications 3:129-146, 2001

40. Ren K, Puig V, Papke RL, Itoh Y, Hughes JA, Meyer EM: Multiple calcium channels and kinases mediate alpha7 nicotinic receptor neuroprotection in PC12 cells. J Neurochem 94: 926-933, 1989 
41. Russo E, Constanti A, Ferreri G, Citraro R, De Sarro G: Nifedipine affects the anticonvulsant activity of topiramate in various animal models of epilepsy. Neuropharmacology 46(6):865-878, 2004

42. Sharifabad MH, Nyengaard JR: Design based estimation of neuronal number and individual neuronal volume in the rat hippocampus. J Neurosci Methods 162: 206-214, 2007

43. Shen EY, Lai YJ: In vivo microdialysis study of excitatory and inhibitory amino acid levels in the hippocampus following penicillin-induced seizures in mature rats. Acta Paediatr Taiwan 43(6): 313-318, 2002

44. Stilwell GE, Saraswati S, Littleton JT, Chouinard SW: Development of a Drosophila seizure model for in vivo highthroughput drug screening. Eur J Neurosci 24(8):2211-2222, 2006

45. Tooyama I, Bellier JP, Park M, Minnasch P, Uemura S, Hisano T, Iwami M, Aimi Y, Yasuhara O, Kimura H: Morphologic study of neuronal death, glial activation, and progenitor cell division in the hippocampus of rat models of epilepsy. Epilepsia 43(Suppl 9):39-43, 2002

46. Veatch LM, Gonzalez LP: Nifedipine alleviates alterations in hippocampal kindling after repeated ethanol withdrawal. Alcohol Clin Exp Res 24(4): 484-491, 2000

47. Weiss JH, Hartley DM, Koh J, Choi DW: The calcium channel blocker nifedipine attenuates slow excitatory amino acid neurotoxicity. Science 247: 1474-1477, 1990

48. Wen P: Nifedipine for epilepsy? Br Med J (Clin Res Ed) 296: 1069,1988
49. West MJ, Slomianka L, Gundersen HJ: Unbiased stereological estimation of the total number of neurons in the subdivisions of the rat hippocampus using the optical fractionator. Anat Rec 231: 482-497, 1991

50. Westphal JF, Trouvin JH, Deslandes A, Carbon C: Nifedipine enhances amoxicillin absorption kinetics and bioavailability in humans. J Pharmacol Exp Ther 255(1):312-317, 1990

51. Wolf OT, Dyakin V, Pate1 A, Vadasz C, De Leon MJ, McEwen $\mathrm{BS}$, Bulloch K: Volumetric structural magnetic resonance imaging (MRI) of the rat hippocampus following kainic acid (KA) treatment. Brain Research 934: 87-96, 2002

52. Xu JH, Long L, Tang YC, Hu HT, Tang FR: Ca(v)1.2, Ca(v)1.3, and $\mathrm{Ca}(\mathrm{v}) 2.1$ in the mouse hippocampus during and after pilocarpine-induced status epilepticus. Hippocampus 17: 235-251, 2007

53. Yilmaz I, Adiguzel E, Akdogan I, Kaya E, Hatip-Al-Khatib I: Effects of second generation tetracyclines on penicillinepilepsy-induced hippocampal neuronal loss and motor incoordination in rats. Life Sci 79:784-790, 2006

54. Zeng YC, Pezzola A, Scotti De Carolis A, Sagratella S: Inhibitory influence of morphinans on ictal and interictal EEG changes induced by cortical application of penicillin in rabbits: A comparative study with NMDA antagonists and pentobarbitone. Pharmacol Biochem Behav 43(2):651-656, 1992 